\title{
Atmospheric warming threatens the untapped glacial archive of Ortles mountain, South Tyrol
}

\author{
P. GABRIELLI, ${ }^{1,2}$ L. CARTURAN, ${ }^{3}$ J. GABRIELI, ${ }^{4,5}$ R. DINALE, $^{6}{ }^{\text {K. KRAINER, }}{ }^{7}$ \\ H. HAUSMANN, ${ }^{8}$ M. DAVIS, ${ }^{2}$ V. ZAGORODNOV,${ }^{1,2}$ R. SEPPI $^{9}{ }^{9}$ C. BARBANTE, ${ }^{4,5}$ \\ G. DALLA FONTANA, ${ }^{3}$ L.G. THOMPSON ${ }^{1,2}$ \\ ${ }^{1}$ School of Earth Sciences, The Ohio State University, 275 Mendenhall Laboratory, 125 South Oval Mall, Columbus, Ohio \\ 43210-1308, USA \\ E-mail: gabrielli.1@osu.edu \\ ${ }^{2}$ Byrd Polar Research Center, The Ohio State University, 1090 Carmack Road, Columbus, Ohio 43210-1002, USA \\ ${ }^{3}$ Department of Land and Agro-forest Environments, University of Padova, Viale dell'Università 16, \\ I-35020 Legnaro (PD), Italy \\ ${ }^{4}$ Department of Environmental Sciences, University of Venice 'Ca' Foscari', Dorsoduro 2137, I-30123 Venice, Italy \\ ${ }^{5}$ Institute for the Dynamics of Environmental Processes - CNR, University of Venice 'Ca' Foscari', Dorsoduro 2137 , \\ I-30123 Venice, Italy \\ ${ }^{6}$ Ufficio Idrografico - Provincia Autonoma di Bolzano, Via Mendola 33, I-39100 Bolzano, Italy \\ ${ }^{7}$ Institute of Geology and Paleontology, University of Innsbruck, Innrain 52, A-6020 Innsbruck, Austria \\ ${ }^{8}$ Institute of Geodesy and Geophysics, Vienna University of Technology, Gusshausstrasse 27-29/128, A-1040 Vienna, Austria \\ ${ }^{9}$ Earth Science Department, University of Pavia, Via Ferrata 1, I-27100 Pavia, Italy
}

\begin{abstract}
Ortles mountain (3905 $\mathrm{m}$ a.s.l.), South Tyrol, Italy, is the highest mountain of the Eastern European Alps, and its upper glacier, Alto dell'Ortles, presents a unique opportunity to obtain the first paleoenvironmental record from an ice core in this area. To study the suitability of this glacier as a drilling site, in 2009 we performed the first preliminary study of its glaciological characteristics at $\sim 3830 \mathrm{~m}$ a.s.l. The maximum thickness is $\sim 75 \mathrm{~m}$, and lamination of the exposed ice layers is excellent down to bedrock. Firn and ice lenses were observed in a $10 \mathrm{~m}$ shallow core, and the firn/ice transition was below $\sim 24 \mathrm{~m}$. The seasonal chemical signal is clearly preserved only within the uppermost 2008 and 2009 snow/firn. A simple mass-balance model, the incipient 'smoothing' of the chemical record, and the observed ice lenses provide evidence that melting, infiltration and refreezing cycles occurred within the firn layers formed before 2008. Nevertheless, the mass balance of the upper part of Alto dell'Ortles was positive $\left(\sim 800 \mathrm{~mm} \mathrm{a}^{-1}\right)$ during the last few years. We suggest that an environmental history is likely to be well preserved only within the ice layers formed before $\sim 1980$, when summer air temperature was $\sim 2{ }^{\circ} \mathrm{C}$ colder than today in this area. Clearly the continued warming trend predicted to occur over the next few decades, and the consequent increase in frequency and/or intensity of infiltration processes, will endanger the preservation of the glacial archive conserved in the deep ice layers of Ortles mountain.
\end{abstract}

\section{INTRODUCTION}

In 1991 the mummy of the now famous Ötzi (Tyrolean Ice Man) was retrieved from an ablating ice saddle, Tisenjoch (3210 m a.s.I.), close to the border between Italy and Austria in the Eastern European Alps (Seidler and others, 1992; Kutschera and Müller, 2003). Until now, only limited attention has been given to the climatic and glaciological value of the ice, now completely melted, that buried and perfectly preserved this mummy for $\sim 5200$ years (Baroni and Orombelli, 1996; Haeberli and others, 2004). Although this was likely fossil ice without any climatic sequence, only one direct study of this potentially valuable ice, describing large organic particles (Bortenschlager and others, 1992), was performed.

The exceptional preservation of the Tyrolean Ice Man provided the first direct evidence that ancient ice (possibly as old as the mummy) survived the Roman and Medieval Warm periods when temperatures in this region might have been at least comparable to those currently recorded (Frisia and others, 2005). Recent analyses of the bottom ice of the Colle Gnifetti core, which was retrieved in 2003 from Monte Rosa (4450 ma.s.I., Western Alps), confirmed that late Pleistocene ice $(\sim 10 \mathrm{kaBP})$ is still present in the Alps; a full Holocene climate record may have been retained in this core (Jenk and others, 2009; Sigl and others, 2009).

One of the most prominent features governing the weather, and ultimately the climate, in Europe is the North Atlantic Oscillation (NAO; Luterbacher and others, 2004). This continental-scale atmospheric feature impacts strongly on temperature and precipitation climate regimes of the Alps, especially during winter (Frisia and others, 2003). The stable atmospheric winter boundary layer, which extends up to $\sim 3000$ ma.s.l. in the Eastern Alps (Kappenberger and Kerkmann, 1997), inhibits mixing between the upper and lower tropospheric levels. Therefore ice originating from winter snow deposited above $\sim 3000$ ma.s.l. may retain information about large-scale atmospheric processes such as those driven by the NAO. In contrast, ice originating from summer snow could be more indicative of local environmental conditions, due to the much stronger convection mixing of the lower and upper tropospheric levels during the warm season, with a nearly uniform height of the boundary layer up to 4200 ma.s.l. (Nyeki and others, 2000). 


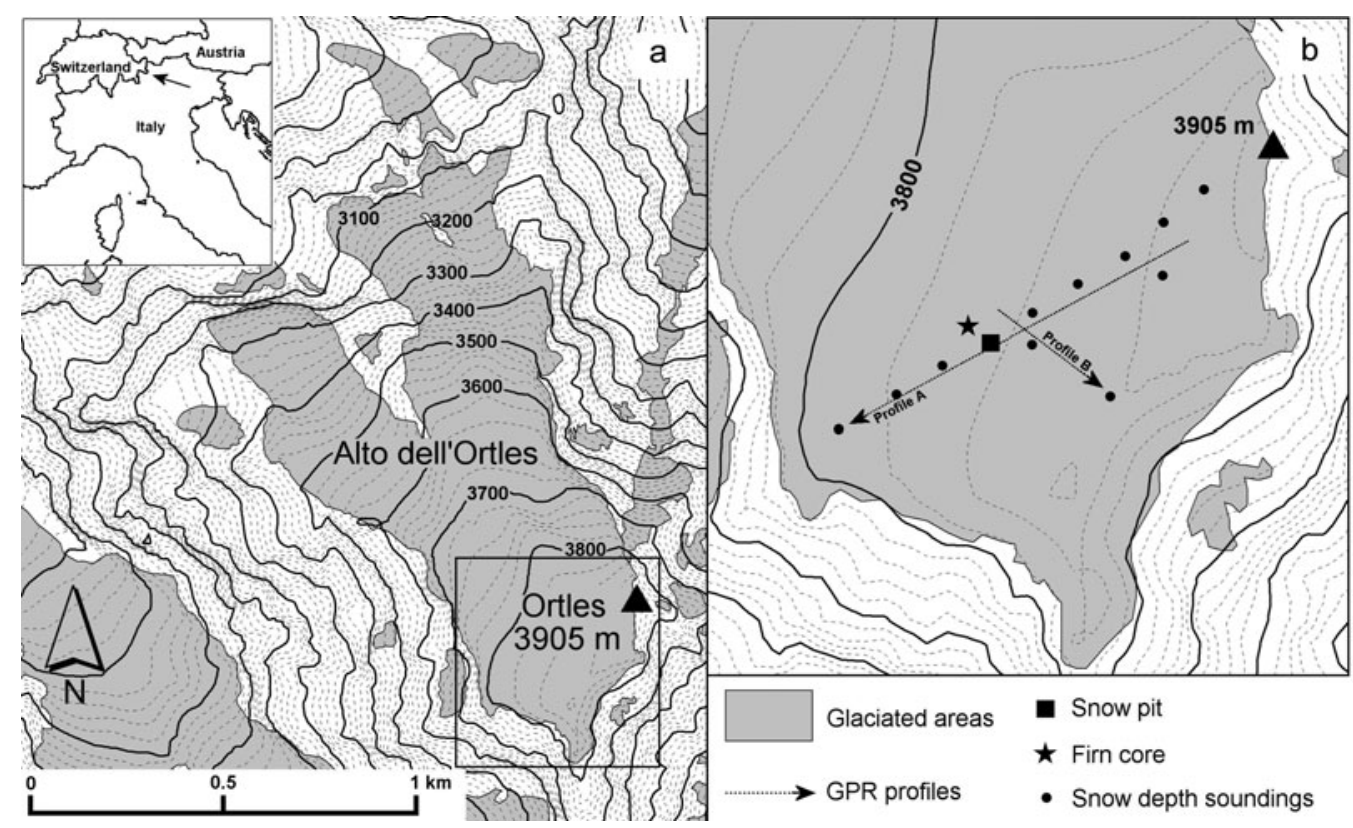

Fig. 1. (a) Map of Alto dell'Ortles, South Tyrol, Italy. (b) Expansion of the boxed area in (a) which is the study area during the 2009 summer glaciological survey.

Ice cores extracted from the Alpine glaciers have the potential to provide information about the physical chemical characteristics of the past environment on centennial to millennial timescales (Van de Velde and others, 2000; Villa and others, 2003; Barbante and others, 2004; Schwikowski and others, 2004; Jenk and others, 2009; Thevenon and others, 2009; Gabrieli and others, 2010). Until now, alpine environmental histories from ice cores have only been obtained from glaciers located in the western sector of the Alps. In this area, the high snow accumulation rates (e.g. Col du Dôme (4250 ma.s.I.) $2200 \mathrm{~mm}$ w.e. $\mathrm{a}^{-1}$; Preunkert and others, 2000) resulted in ice-core records that extended back over timescales of hundreds of years. At Colle Gnifetti, where the accumulation rate is much lower $(200-400 \mathrm{~mm}$ w.e. $\mathrm{a}^{-1}$ ), a longer ice-core record was obtained (Jenk and others, 2009). However, in this particular case, the erosion of much of the winter snow (Wagenbach and others, 1988) may have impeded a complete registration of large-scale climatic features like the NAO.

The Eastern Alps lie at the boundary between the central and southern European climate regions (Davis and others, 2003) and therefore may have experienced a different climatic history than the Western Alps (Frisia and others, 2005), especially in terms of precipitation (see below). Unfortunately, there are no ice cores from the entire eastern sector of the Alps. This is mainly because the highest glaciers in this area lie at lower elevations $(<4000 \mathrm{~m}$ a.s.l.) than in the Western Alps and thus are probably assumed to be affected by strong summer meltwater percolation that will have completely altered any potential climatic record. However, glaciers below $4000 \mathrm{~m}$ a.s.l. with northern exposure in the northwestern sector of the Alps have provided extremely valuable atmospheric ice-core records, such as those from Fiescherhorn glacier (3890 ma.s.I., Swiss Alps) (Schwikowski and others, 1999).

Alto dell'Ortles is the highest glacier (3018-3905 m a.s.l.) in the Eastern Alps and is located on Ortles mountain $\left(46^{\circ} 30^{\prime} 32^{\prime \prime} \mathrm{N}, 10^{\circ} 32^{\prime} 41^{\prime \prime} \mathrm{E}\right)$, close to the border between Italy, Switzerland and Austria (Fig. 1). Until now this glacier has not been investigated, in part due to its difficult access. This area experiences a continental precipitation regime, and is often referred to as the inner dry Alpine zone (Frei and Schär, 1998) because it records the lowest amounts of precipitation in the Alps. For example, Silandro, Venosta valley (718 $\mathrm{m}$ a.s.I.), receives $\sim 500 \mathrm{~mm} \mathrm{a}^{-1}$ (http://www. provincia.bz.it/hydro/wetterdaten/Pdf/Silandro/1-0905-PSSilandro-Schlanders.pdf), which is lower by a factor of two to three than the Alpine average (Schwarb, 2000).

Glaciers in this area thus have the potential to contain older ice than in other sectors of the Alps. As the $\sim 5200$ year old Tyrolean Ice Man was discovered just $\sim 30 \mathrm{~km}$ from Ortles mountain, Alto dell'Ortles presents a unique opportunity to investigate whether ancient ice is still present in this sector of the Alps. This ice may show a high-altitude environmental record containing continental-scale climatic features like the NAO displaying different histories than those obtained in the Western Alps.

Here we report the first glaciological data from Alto dell'Ortles. By studying the glaciochemical and geophysical characteristics of the top part of this glacier, we aim to investigate whether this could be a suitable site for extracting a long-term environmental record from an ice core drilled to bedrock. In particular, we present the first estimates of the glacier thickness, the short-term snow accumulation rate and whether the atmospheric seasonal signal is retained in the shallow snow and firn layers.

\section{STUDY AREA}

Some of the largest glacierized areas in the Eastern Alps are in the Ortles-Cevedale massif. Ortles mountain $(3905 \mathrm{~m}$ a.s.l.) used to be the highest mountain in the Habsburg Empire (AD 1278-1918) and is the highest summit of the Eastern Alps. The northwestern side of Ortles mountain is covered by Alto dell'Ortles, which gently slopes $\left(8-9^{\circ}\right)$ from near the summit ( 3860 ma.s.l.; Figs 1 and $2 \mathrm{a}$ and b) for $\sim 300 \mathrm{~m}$, and then flows on steeper bedrock in two major 'tongues', to its lowest elevation of $3018 \mathrm{~m}$ a.s.l. Its total 

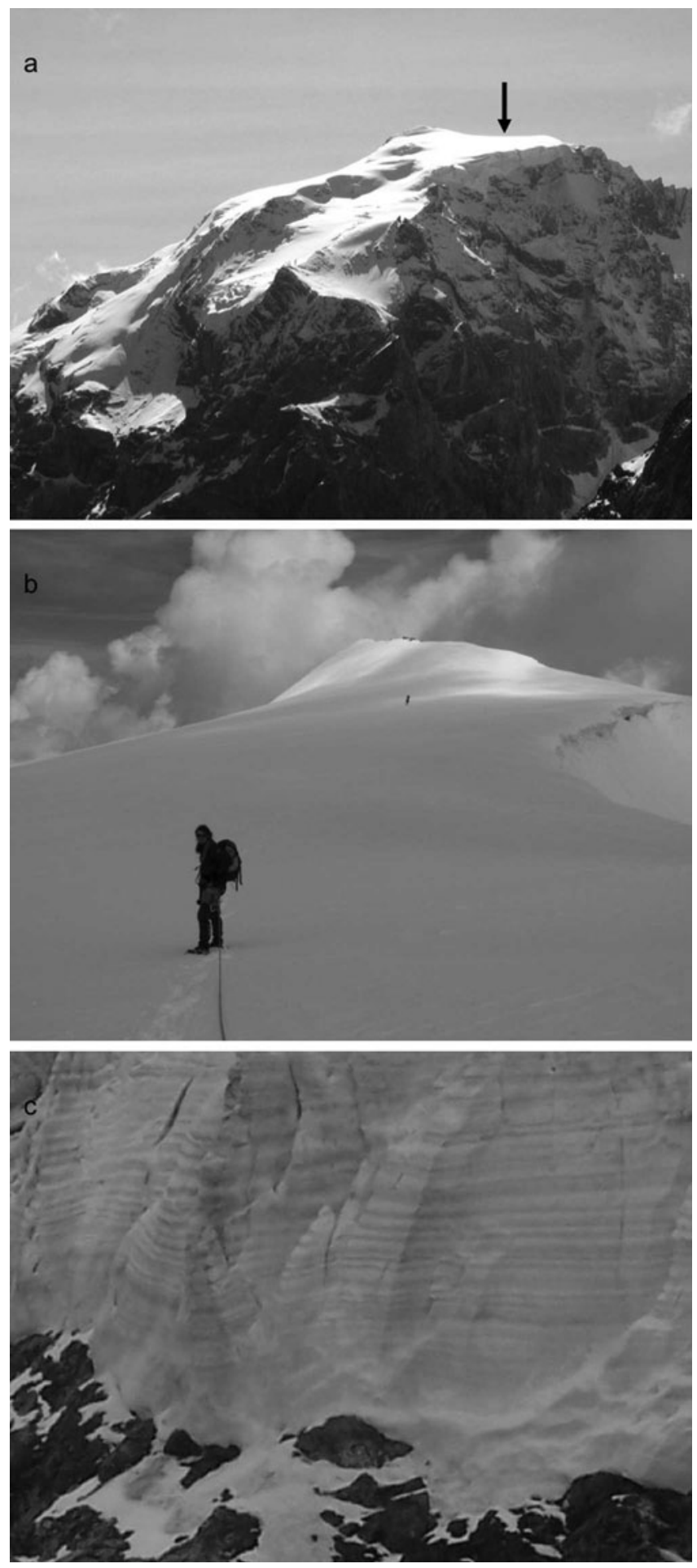

Fig. 2. (a) The northwest flank of Ortles mountain showing Alto dell'Ortles in July 2004. The arrow points to the potential drilling site. (b) The upper part of this glacier at $\sim 3860 \mathrm{~m}$ a.s.l., with the summit of Ortles mountain (3905 m a.s.I.) in the background, in July 2007. (c) Ice layers on the northern-exposed glacial margins at $\sim 3750$ m a.s.l.

surface area is $1.04 \mathrm{~km}^{2}, \sim 10 \%$ of which constitutes the upper, gentle slopes. The main access to this glacier is the technically difficult climbing route to the summit of Ortles mountain, which is located on its north ridge. This probably prevented any glaciological investigation until the summers of 2007 and 2008 when we climbed the mountain to perform the first close observations of the general features of

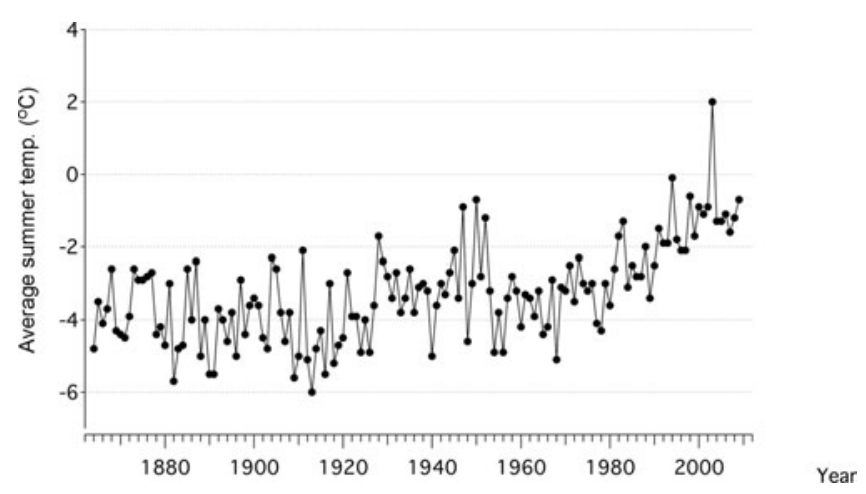

Fig. 3. Average summer air-temperature reconstruction at $3850 \mathrm{~m}$ a.s.I. in the Ortles mountain area during the period 1864-2009.

Alto dell'Ortles. On 12 June 2009, using high-altitude helicopters, we reached this glacier where we performed the first extensive glaciological survey.

\section{METHODOLOGY}

\section{Air-temperature and mass-balance reconstructions}

Meteorological parameters have never been recorded on Ortles mountain. We therefore attempted a preliminary reconstruction of summer air temperature and mass balance on Alto dell'Ortles from data obtained from a few surrounding stations. Using the 1864-2009 air-temperature record from Säntis $(\sim 120 \mathrm{~km}$ northwest; $2502 \mathrm{~m}$ a.s.l.; MeteoSwiss, http://www.meteoswiss.admin.ch/web/en/ climate/climate_today/homogeneous_data.html) and the 1960-2009 record from Caresér 'diga' ( 15 km southwest; 2605 ma.s.l.; Meteotrentino, http://www.meteotrentino.it/ dati-meteo/stazioni/elenco-staz-hydstra.aspx?ID=151), we calculated, via the humidity lapse rate, an 1864-2009 summer (June-August) temperature $\left(T_{\mathrm{s}}\right)$ record for the Ortles mountain area at 3850 ma.s.I. (Fig. 3).

We also attempted to reconstruct the preliminary 200309 mass balance, $b_{n}$, of Alto dell'Ortles. Based on our previous snow-cover observations in the Ortles-Cevedale massif (Carturan, 2010), each mass-balance year was assumed to start on 1 September and end on 31 August. We used a simple model employing two functions to estimate the total accumulation, $c_{t}$, and the melt component, $a_{\mathrm{t}}$, by adopting daily time-steps:

$$
b_{\mathrm{n}}=c_{\mathrm{t}}\left(P_{\mathrm{s}}\right)+a_{\mathrm{t}}\left(T_{\max }\right),
$$

where $P_{\mathrm{S}}$ is the precipitation recorded at $1910 \mathrm{~m}$ a.s.l. in the underlying village of Solda $(\sim 4 \mathrm{~km}$ from the summit of Ortles mountain) and $T_{\max }$ is the daily maximum air temperature reconstructed for the Ortles mountain area at $3830 \mathrm{~m}$ a.s.l.

The component $c_{\mathrm{t}}$ was parameterized as $c_{\mathrm{t}}=K_{\mathrm{p}} P_{\mathrm{s}}$, where $K_{\mathrm{p}}=1.71$ is the ratio between the snow accumulated (measured in w.e.; see below) on Alto dell'Ortles at $3830 \mathrm{~m}$ during the 2008/09 winter and the total precipitation recorded in Solda over the same period. $K_{\mathrm{p}}$ is assumed to be constant and accounts for vertical precipitation gradients and snow redistribution effects. The component $a_{\mathrm{t}}$ was calculated using the degree-day approach (Ohmura, 2001; Hock, 2003), where $\mathrm{a}_{\mathrm{t}}=K_{\mathrm{a}} T_{\max }$ ( $K_{\mathrm{a}}$ is the melt factor). The value of $K_{\mathrm{a}}=1.7 \mathrm{~mm}^{\circ} \mathrm{C}^{-1}$ was found by calibrating the 


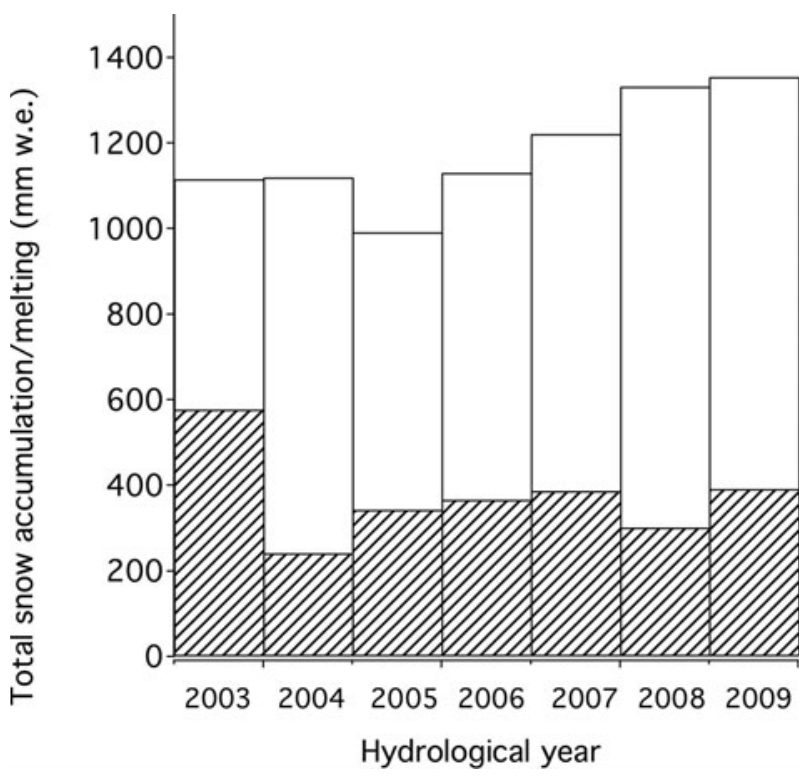

Fig. 4. Modeled total snow accumulation in the Ortles mountain area at $3830 \mathrm{~m}$ a.s.I. during the period 2003-09. Shading indicates the melted fraction, while the open part of each bar indicates the annual mass balance.

model with the 2009 summer mass balance measured on Alto dell'Ortles, as discussed below.

We emphasize that this modeling scheme constitutes just a first attempt to reconstruct the mass balance of Alto dell'Ortles. Clearly, further studies are required to perform more accurate calculations. In particular, local vertical temperature and precipitation gradients, snow redistribution, albedo and internal accumulation processes (melting, percolation and refreezing) require further investigation, as does the behavior of the meteorological variables at high altitude in the Eastern Alps.

\section{Shallow core}

In June 2009 a $10 \mathrm{~m}$ shallow core was drilled using a lightweight hand auger on Alto dell'Ortles at $3830 \mathrm{~m}$ a.s.l. The borehole temperature was measured at $\sim 10 \mathrm{~m}$ depth with a calibrated thermistor $\left(T_{10}=-1.2^{\circ} \mathrm{C}\right.$; discussed later). The shallow-core sections were handled with low-density polyethylene (LDPE) gloves, cut into $\sim 10 \mathrm{~cm}$ samples, weighed, packed in plastic bags and transported frozen to the University of Venice. Here the samples were cut in half length-wise, melted, and the water poured into LDPE plastic bottles. These aliquots were analyzed at The Ohio State University (OSU) using conventional methods for analysis of the soluble and insoluble content and stable isotopes. Majorion concentrations $\left(\mathrm{SO}_{4}{ }^{2-}, \mathrm{NO}_{3}{ }^{-}, \mathrm{NH}_{4}{ }^{+}, \mathrm{Ca}^{2+}, \mathrm{Mg}^{2+}, \mathrm{K}^{+}\right.$, $\mathrm{Na}^{+}, \mathrm{Cl}^{-}$and $\mathrm{F}^{-}$) were determined using Dionex Model 2500 ion chromatographs (Buck and others, 1992). The concentrations and size distributions of mineral dust were measured with a Beckman Coulter Multisizer 4 (Thompson, 1977), and stable-isotopic ratios $\left(\delta \mathrm{D}, \delta^{18} \mathrm{O}\right)$ were analyzed with Finnigan Mat Delta+ mass spectrometers (Craig, 1957).

\section{Snow pit}

A snow pit of $4.9 \mathrm{~m}$ depth was excavated $\sim 13 \mathrm{~m}$ from the drilling site. Observational methods based on international standards were used to describe morphological and physical characteristics of the snow/firn (Fierz and others, 2009). The physical parameters measured were density, temperature, resistance to penetration (hardness index) and crystal shape/ size. Two ablation sticks were installed next to the snow pit in June 2009 using a basal metallic tablet to prevent sinking, and were measured again at the end of August 2009. To gather information on snow distribution and firn stratification, 12 snow depth soundings were performed in June 2009 along a $\sim 300 \mathrm{~m}$ transect on Alto dell'Ortles (Fig. 1b) by probing down resistant layers. The snow pit was sampled using acid pre-cleaned LDPE Nalgene vials and clean-room clothing (Gabrielli and others, 2008). These samples were also transported frozen to the University of Venice where they were analyzed for major ions by ion chromatography, and for trace elements by inductively coupled plasma sectorfield mass spectrometry (ICP-SFMS) in accordance with wellestablished procedures (Barbante and others, 1999). Aliquots were also sent to OSU for stable-isotope measurements.

\section{Georadar}

Georadar (ground-penetrating radar (GPR)) data were specifically used for glacier depth measurements and were collected using a GSSI SIR 2000 system in combination with a multiple low-frequency $15 \mathrm{MHz}$ antenna. This low frequency is better suited to detect the bedrock and thus tends to underemphasize the internal glacial features. The data were acquired at points along two profiles (A and B; Fig. 1b) using an antenna spacing of $4 \mathrm{~m}$. For the $15 \mathrm{MHz}$ antenna $(\lambda=12 \mathrm{~m}$ ) the vertical resolution is $\pm 3 \mathrm{~m}$. The spatial sample interval was $1.4 \mathrm{~m}$ on profile $A(360 \mathrm{~m})$ and $1 \mathrm{~m}$ on profile $B$ $(143 \mathrm{~m})$. The main recording parameters were $1000 \mathrm{~ns}$ record length, 1024 samples per scan, 16 bits per sample and 32 -fold vertical stacking. The raw data were processed with an automatic gain control function, bandpass filter, migration velocity analyses, migration, time-to-depth conversion and static corrections, using the two-dimensional software ProMAX. From the glaciological observations (see below) we derived a snow depth of $\sim 3 \mathrm{~m}$ and an upper limit of the firn/ice transition at $\sim 24 \mathrm{~m}$. Accordingly, the velocity field for the time-to-depth conversion was defined as $0.24 \mathrm{~m} \mathrm{~ns}^{-1}$ in dry snow (Frolov and Macheret, 1999), $0.20 \mathrm{~m} \mathrm{~ns}^{-1}$ in firn (Span and others, 2005) and $0.167 \mathrm{~m} \mathrm{~ns}^{-1}$ in ice.

\section{RESULTS}

\section{Air-temperature and mass-balance reconstructions}

The average reconstructed summer temperature, $T_{\mathrm{s}} \pm \sigma$, in the Ortles mountain area at $3850 \mathrm{~m}$ a.s.l. was $-3.7 \pm 1.0^{\circ} \mathrm{C}$ during the 1864-1979 time period, while it was $-1.6 \pm 1.1^{\circ} \mathrm{C}$ during the last three decades (1980-2009), pointing to a recent warming that peaked in 2003 with an inferred exceptionally positive $T_{\mathrm{s}}$ of $2^{\circ} \mathrm{C}$ (Fig. 3).

The calculated total snow accumulation, $c_{t}$, between 2003 and 2009 averaged $\sim 1200 \mathrm{~mm} \mathrm{a}^{-1}$, with a minimum of $\sim 1000 \mathrm{~mm}$ in 2005 and a maximum of $\sim 1350 \mathrm{~mm}$ in 2009 (Fig. 4). $T_{\max }$ ranged between $-12.9^{\circ} \mathrm{C}$ and $8.9^{\circ} \mathrm{C}$ in summer over the same period. The average reconstructed total melt, $a_{\mathrm{t}}$, was $\sim 400 \mathrm{~mm} \mathrm{a}^{-1}$, with a minimum of $\sim 250 \mathrm{~mm}$ in 2004 and a maximum of $\sim 600 \mathrm{~mm}$ in 2003 (Fig. 4). The modeled summer mass balance was remarkably variable from year to year. It was negative in $2003(\sim-250 \mathrm{~mm})$, near zero in 2005, 2006 and 2009, and positive in 2004, 2007 and 2008 (with a maximum of $\sim 350 \mathrm{~mm}$ in 2008). The average calculated mass balance, $b_{n}$, from 2002 to 2009 was 
$\sim 800 \mathrm{~mm} \mathrm{a}^{-1}$ (minimum in 2003 of $\sim 550 \mathrm{~mm}$, maximum in 2008 of $\sim 1050 \mathrm{~mm})$.

The calculated annual mass balance is possibly underestimated because, by assuming meltwater drainage, we did not take into account internal accumulation due to eventual meltwater percolation and refreezing. Internal accumulation may indeed constitute a significant factor in the mass balance of a nearly isothermal glacier like Alto dell'Ortles (see below). For instance, at Storglaciären, Sweden, this varies from $3-5 \%$ of the annual accumulation (Schneider and Jansson, 2004) to $20 \%$ of winter accumulation (Reijmer and Hock, 2008). On five Alaskan glaciers, internal accumulation was estimated to range from $7 \%$ to $64 \%$ of the net accumulation (Trabant and Mayo, 1985).

\section{Glaciological and geophysical observations}

The exposed margins of this glacier show excellent lamination of the ice layers down to bedrock (Fig. 2c). From direct observations and density measurements of the shallow core $\left(242-751 \mathrm{~kg} \mathrm{~m}^{-3}\right.$, with a mean of $476 \mathrm{~kg} \mathrm{~m}^{-3}$ ) we conclude that the top $10 \mathrm{~m}$ of the glacier is composed mainly of snow and firn (Fig. 5). We also observed numerous horizontal and tilted ice lenses (especially below $3.20 \mathrm{~m}$ of the core depth) indicating frequent surface and/or internal melting and refreezing.

From the sounding profile performed on the upper part of Alto dell'Ortles (Fig. 1b), the snow depth (winter/spring accumulation) was found to be homogeneous $(2.40 \pm 0.30 \mathrm{~m}$ depth or $910 \pm 130 \mathrm{~mm}$ w.e. as calculated using the snow-pit density measurements). Other transitions in the sounding profile were detected at $\sim 3.50$ and $\sim 4.50 \mathrm{~m}$ depth. Taking these as the firn transitions during the two previous years, accumulations of $\sim 620 \mathrm{~m}$ w.e. (2008) and $\sim 480$ m w.e. (2007) can be inferred. If we consider the density measurements from the shallow core, the annual accumulation derived according to the proposed chronology (see below) is 476 (2008), 470 (2007), 1068 (2006) and 1191 (2005). Despite the large interannual variability, the core yields a preliminary average accumulation rate of $\sim 800 \mathrm{~mm}$ w.e. $\mathrm{a}^{-1}$, which is in agreement with our modeled value $\left(\sim 850 \mathrm{~mm}\right.$ w.e. $\left.\mathrm{a}^{-1}\right)$ over the same period.

From observation of various curves describing the relationship between snow/firn density and glacier depth at similar Alpine sites (e.g. Jenk, 2006), the assumption of a linear behavior between $\sim 400$ and $\sim 800 \mathrm{~kg} \mathrm{~m}^{-3}$ appears to be a first reasonable approximation (Fig. 5). This simple approach allows us to extrapolate from the shallow core an upper limit of the firn/ice transition depth at 22-26 m, assuming that glacier ice forms in a density range of 830 $917 \mathrm{~kg} \mathrm{~m}^{-3}$ (Paterson, 1994). For comparison, a firn/ice transition at $45 \mathrm{~m}$ depth was observed at the higher-altitude site of Colle Gnifetti (Keck, 2001; Eisen and others, 2003).

While temperatures measured down to $4.50 \mathrm{~m}$ depth in the snow pit certainly respond to seasonal-scale or even shorter thermal variations in the atmosphere, the temperature recorded at $\sim 10 \mathrm{~m}$ depth, $T_{10}$, can be considered to be closer to the thermal state of the glacier (Zagorodnov and others, 2006; Fig. 5). A $T_{10}$ of $-1.2^{\circ} \mathrm{C}$ was measured in the borehole. Although we cannot rule out that higher temperatures may occur deeper in the glacier, our measurement suggests that this glacier is close to the boundary that separates a temperate (i.e. ice-body temperatures are uniform around the pressure-melting temperature (PMT)) from a polythermal glacier (i.e. temperatures vary from the PMT to below the

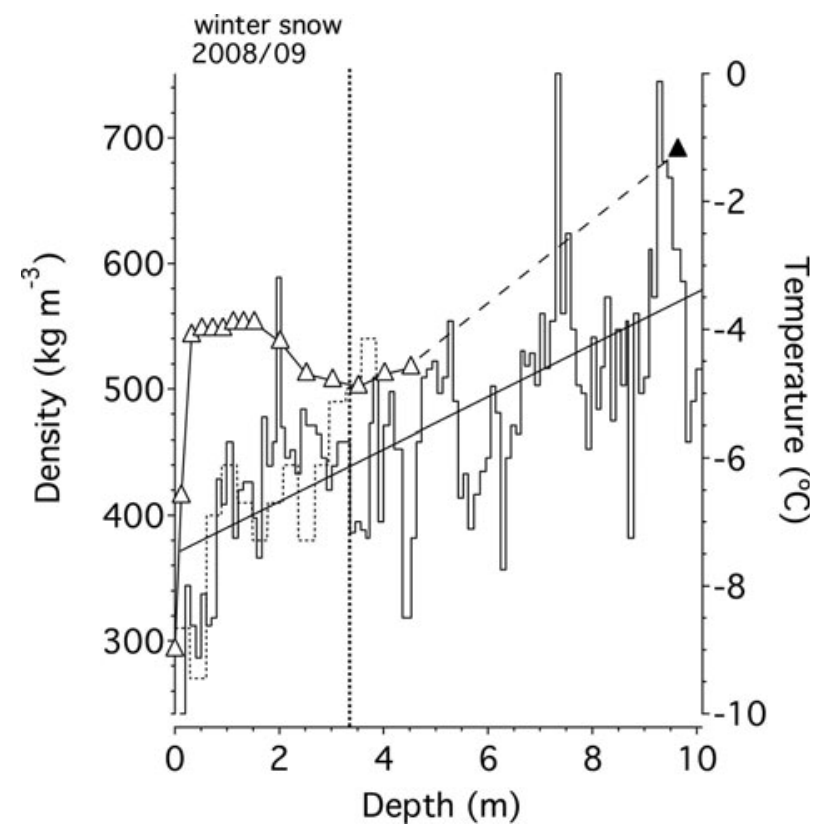

Fig. 5. Snow and firn density obtained from the shallow core (solid curve) and the snow pit (dotted curve). Also shown is the linear trend of the density, $D$, versus depth, $H\left(D=21 H+369 ; R^{2}=0.47\right)$. The graph also displays the firn temperature recorded in the snow pit (open triangles) and at $\sim 10 \mathrm{~m}$ in the borehole (filled triangle).

freezing level). Taking the reconstructed mean annual air temperature in the Ortles mountain area over the last few years $\left(T_{\mathrm{a}} \approx-9^{\circ} \mathrm{C}\right)$, the derived $T_{10}$ for the glacier will be $\sim-4^{\circ} \mathrm{C}$, according to the equation $T_{10}=1.2 T_{\mathrm{a}}+6.7$ (Zagorodnov and others, 2006). The discrepancy between the observed and the reconstructed $T_{10}$ suggests that percolation-refreezing processes have released a significant amount of latent heat in the firn layers, thereby increasing $T_{10}$.

To calculate the depth of the glacier using the GPR, we applied the velocity-depth function described above. The signal-processed section (supplementary Fig. 1) displays two major sets of diffraction hyperbolas located (1) in the glacier at 300-500 ns $\left(v \approx 0.195 \mathrm{~m} \mathrm{~ns}^{-1}\right)$ and $(2)$ near a basal reflector at $700-900 \mathrm{~ns}\left(v \approx 0.18 \mathrm{~m} \mathrm{~ns}^{-1}\right)$. This indicates the presence of a layer characterized by a velocity higher than in ice (0.167 $\mathrm{m} \mathrm{ns}^{-1}$; Hubbard and Glasser, 2005). To image the correct position of the reflectors, we show a migrated GPR section in Figure 6, along with the interpretation of the bedrock topography. A pronounced basal reflector at $\sim 70 \mathrm{~m}$ depth can be correlated in both radar sections (Fig. 6a and b). Diffraction hyperbolas at this interface are in agreement with the introduced velocity-depth function. In profile $A$ the pronounced basal reflector dips from $\sim 55$ to $\sim 75 \mathrm{~m}$ depth (Fig. 6a). Subsequently, this reflector likely undulates at this depth, as indicated at the intersection point with profile B. This is also supported by the presence of diffraction hyperbolas along this interface (supplementary Fig. 1 at http:// www.igsoc.org/journal/56/199/10J059_Suppl_Fig1.pdf). In conclusion, the compounded view of the bedrock topography (Fig. 6c) strengthens our interpretation that the observed basal reflector represents the glacier bedrock at $\sim 70 \mathrm{~m}$ depth.

\section{Chemistry of snow and firn layers}

Analyses of the shallow-core samples show that $\delta \mathrm{D}$ and $\delta^{18} \mathrm{O}$ are correlated along the expected equilibrium line $\left(R^{2}=0.99\right.$; 


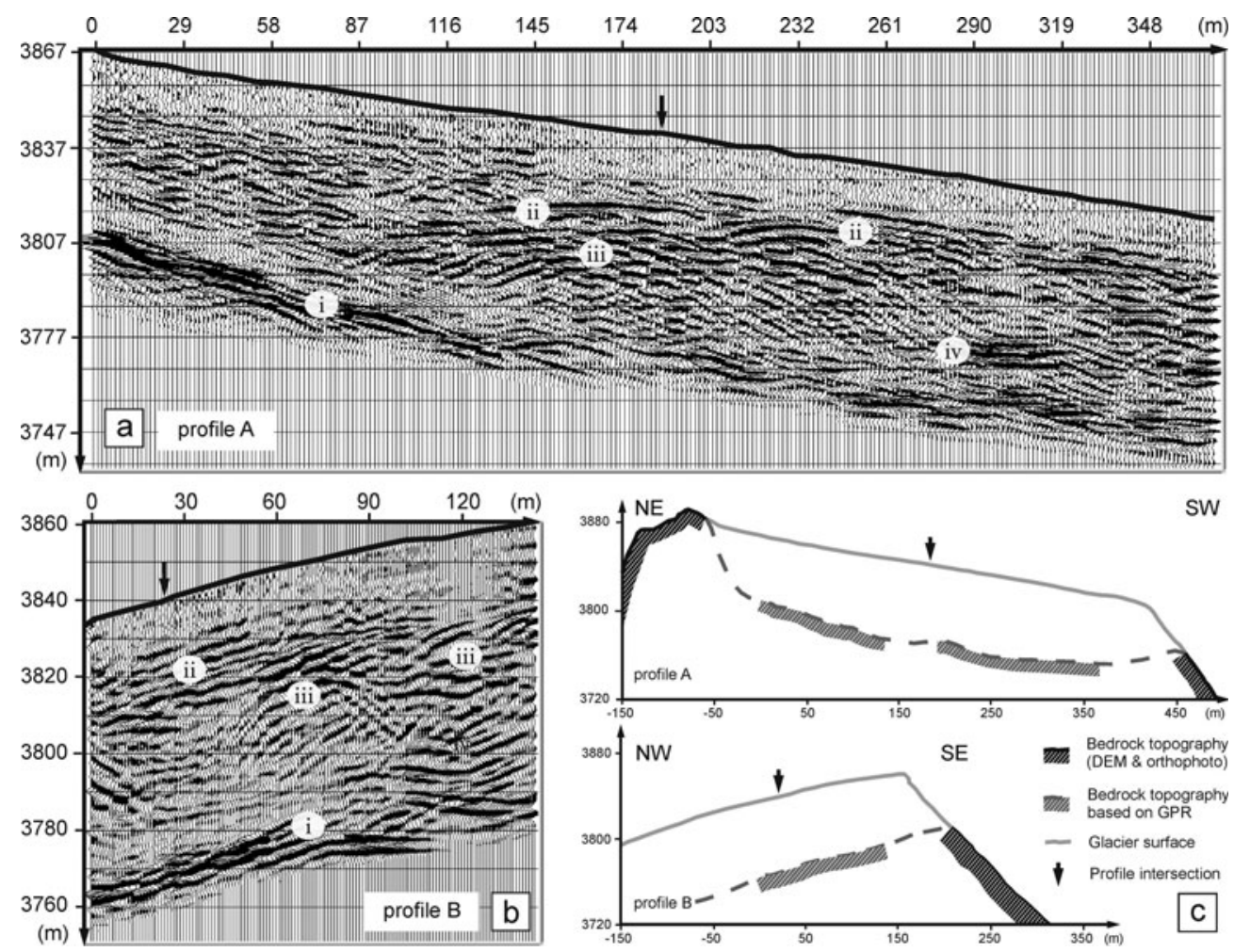

Fig. 6. GPR sections recorded with the $15 \mathrm{MHz}$ antennae and interpretation of the bedrock topography of Alto dell'Ortles. The migrated section with topographic correction for profile A is shown in (a), with the following items highlighted: (i) pronounced basal reflector at the glacier bottom, (ii) continuous reflectors near the assumed firn/ice transition, (iii) a zone of point-source reflectors located close to the assumed firn/ice transition, and (iv) strong reflectors near the basal reflector. Profile B is shown in (b), with the same items noted. (c) Vertical sections of the glacier and interpretation of the bedrock topography.

$\left.\delta^{18} \mathrm{O}=7.99 \delta \mathrm{D}+10.26\right)$ (Craig, 1961). Their values show higher variability in the upper layers (in a range -60 to $-160 \%$ for $\delta \mathrm{D}$ and -6 to $-23 \%$ for $\delta^{18} \mathrm{O}$ ) than in the deeper part of the core $(-80$ to $-120 \%$ for $\delta \mathrm{D} ;-10$ to $-15 \%$ or $\delta^{18} \mathrm{O}$ ) (Fig. 7; supplementary Table 1 at http:// www.igsoc.org/journal/56/199/10J059_Suppl_Table1.pdf. A decrease in the variability of $\delta^{18} \mathrm{O}$ with depth was observed in the shallow firn layers at the low-latitude drilling site of Quelccaya, southern Peru (Thompson, 1980), and in the Arctic snowpack (Moran and Marshall, 2009), and is either due to diffusion or meltwater percolation (Paterson, 1994). The mean isotopic values $\left(\delta \mathrm{D}=-96 \%, \delta^{18} \mathrm{O}=-13 \%\right.$ ) are similar to those found at other drilling sites in the Western Alps at comparable elevations (Schwikowski and others, 1999; Preunkert and others, 2000) (Table 1).

Similar to the stable isotopes, major-ion and dust concentrations are also variable. The mean concentrations of $\mathrm{NO}_{3}{ }^{-}, \mathrm{NH}_{4}{ }^{+}, \mathrm{Ca}^{2+}, \mathrm{Mg}^{2+}, \mathrm{Na}^{+}$and $\mathrm{Cl}^{-}$are higher by a range of factors (up to a maximum of $\sim 5$ for $\mathrm{Ca}^{2+}$ ) than those observed in Col du Dôme and Fiescherhorn, while $\mathrm{SO}_{4}{ }^{2-}$ is lower by a factor of $\sim 2$ (Table 1 ). This is due to different aerosol sources and/or a lower snow accumulation rate at Alto dell'Ortles. $\mathrm{SO}_{4}{ }^{2-}, \mathrm{NO}_{3}{ }^{-}, \mathrm{NH}_{4}{ }^{+}$show high correlations $\left(R^{2}=0.80\right)$ with each other, while $\mathrm{Ca}^{2+}, \mathrm{Mg}^{2+}, \mathrm{F}^{-}\left(R^{2}=0.66-\right.$ $0.95)$ and $\mathrm{Na}^{+}, \mathrm{Cl}^{-}, \mathrm{K}^{+}\left(R^{2}=0.31-0.64\right)$ constitute two distinct groups of variables. These three groups are parts of the anthropogenic $\left(\mathrm{SO}_{4}{ }^{2-}, \mathrm{NO}_{3}{ }^{-}, \mathrm{NH}_{4}{ }^{+}\right)$, crustal $\left(\mathrm{Ca}^{2+}\right.$, $\left.\mathrm{Mg}^{2+}, \mathrm{F}^{-}\right)$and marine $\left(\mathrm{Na}^{+}, \mathrm{Cl}^{-}, \mathrm{K}^{+}\right)$components that characterize Alpine aerosols (Schwikowski and others, 1999; Preunkert and others, 2000; Eichler and others, 2004; Gabrielli and others, 2008).
There is a correspondence between the highest concentrations of the anthropogenic component $\left(\mathrm{SO}_{4}{ }^{2-}, \mathrm{NO}_{3}{ }^{-}\right.$, $\mathrm{NH}_{4}{ }^{+}$) and the stable isotopes (Fig. 7a and b), in the uppermost snow and firn layers of the shallow core. Similar matches with the isotopic ratios are not apparent for the crustal $\left(\mathrm{Ca}^{2+}, \mathrm{Mg}^{2+}, \mathrm{F}^{-}\right)$and marine components $\left(\mathrm{Na}^{+}, \mathrm{Cl}^{-}\right.$, $\mathrm{K}^{+}$) (not shown). An explanation for this is that the anthropogenic contaminants are mostly deposited during the summer when the intense atmospheric convection transports low-altitude pollutants to the higher levels (e.g. Preunkert and others, 2000). By contrast, the major ions representing the crustal and marine components do not show any seasonality. This was also observed in the Western Alps (Schwikowski and others, 1999; Preunkert and others, 2000).

Our data show that, despite the warm summer temperature $\left(T_{\mathrm{s}}=-1.2^{\circ} \mathrm{C}\right)$ and subsequent melting ( $300 \mathrm{~mm}$ w.e. $)$ in 2008, the seasonal variations of the stable isotopes $\mathrm{SO}_{4}{ }^{2-}$, $\mathrm{NO}_{3}{ }^{-}$and $\mathrm{NH}_{4}{ }^{+}$were clearly recorded in the uppermost snow and firn layers of Alto dell'Ortles. Nevertheless, we also note the major-ion variability is attenuated in the lower part of the firn core, likely as a result of more intense meltwater percolation that may have disturbed the few previous seasonal cycles.

By taking into account the stable-isotopic ratios and the concentrations of the anthropogenic contaminants (both displaying maxima and minima during warm and cold intervals respectively) an annual stratigraphy can be reconstructed. Given the existing uncertainty in counting the annual layers, especially before 2007, we developed a tentative chronology of the shallow core, which assigns summer 2004 to the bottom (Fig. 7). This implies a 


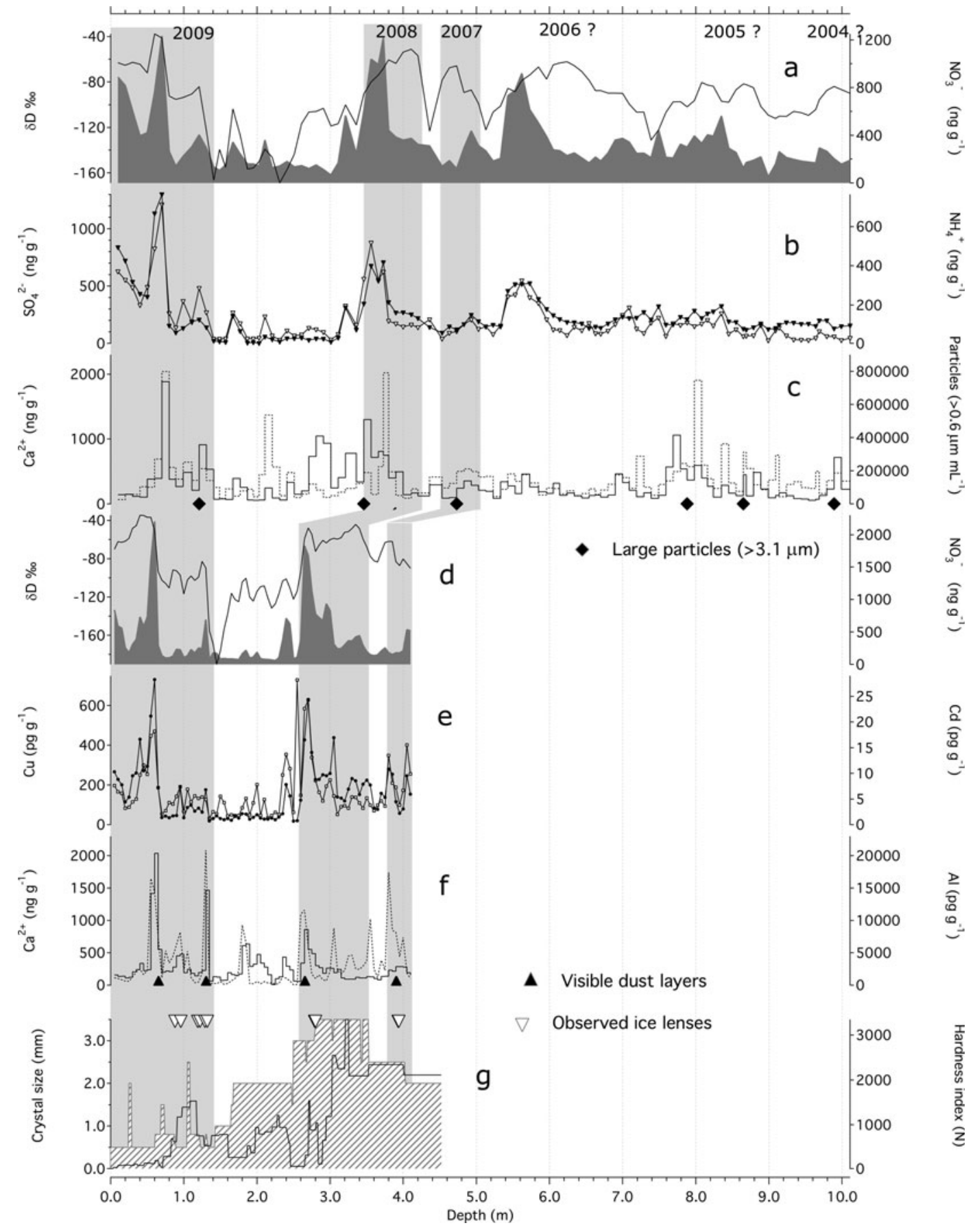

Fig. 7. Comparison of the chemical profiles of the shallow core $(\mathrm{a}-\mathrm{c})$ and the snow pit $(\mathrm{d}-\mathrm{g})$. Shading indicates the annual warm intervals identified by using the data displayed in this graph. In (a) and (d), $\delta \mathrm{D}$ is shown as a solid curve and $\mathrm{NO}_{3}{ }^{-}$as a grey area; in (b) $\mathrm{SO}_{4}{ }^{2-}$ is shown by open diamonds, and $\mathrm{NH}_{4}{ }^{+}$by black diamonds; in (c) and (f) $\mathrm{Ca}^{2+}$ is shown by a solid curve, and dust (c) and $\mathrm{Al}$ ( $\mathrm{f}$ ) by dotted lines; in (e) $\mathrm{Cd}$ is depicted by open squares and $\mathrm{Cu}$ by filled squares; in ( $\mathrm{g}$ ) the crystal size is shown by a hatched area, and hardness index by a solid curve.

measured accumulation of $\sim 4800 \mathrm{~mm}$ w.e. from summer 2004 to June 2009, which compares well with the accumulation of $\sim 4500 \mathrm{~mm}$ w.e. calculated using our model over the same period.

The seasonal signals of the major chemical variations show a $\sim 0.80 \mathrm{~m}$ vertical offset in the snow pit compared with the core (Fig. $7 \mathrm{~d}-\mathrm{g}$ ). However, the two records closely replicate each other down to $\sim 4 \mathrm{~m}$ depth. From comparison of the stable-isotope records and from snow depth soundings, this $\sim 0.80 \mathrm{~m}$ offset might have been caused by an anomalously high winter 2008/09 accumulation at the borehole (1331 mmw.e.). In fact, when this is taken into account, the 2009 and 2008 summer concentration peaks of $\mathrm{SO}_{4}{ }^{2-}, \mathrm{NO}_{3}{ }^{-}$and $\mathrm{NH}_{4}{ }^{+}$occur at $0-0.70$ and $2.50-3.30 \mathrm{~m}$ depth respectively, in the snow pit. In addition, it appears that, in the pit dust, proxies such as $\mathrm{Ca}^{2+}$ and $\mathrm{Al}$ are not linked to any obvious seasonal fallout (Fig. 7f).

Concentrations of trace elements such as $\mathrm{Cu}$ and $\mathrm{Cd}$ in the pit peak concomitantly with $\mathrm{SO}_{4}{ }^{2-}, \mathrm{NO}_{3}{ }^{-}$and $\mathrm{NH}_{4}{ }^{+}$ (Fig. 7e). $\mathrm{Cu}$ and $\mathrm{Cd}$ can also be considered to be diagnostic of the anthropogenic aerosol fallout (median $\mathrm{EF}_{\mathrm{C}}(\mathrm{Cu})=17$ and $\left.\mathrm{EF}_{\mathrm{C}}(\mathrm{Cd})=142\right) . \mathrm{EF}_{\mathrm{c}}(\mathrm{Cu})$ is the crustal enrichment factor of $\mathrm{Cu}$ that is given by $\left\{[\mathrm{Cu}]_{\text {ice }} /[\mathrm{Ba}]_{\text {ice }}\right\} /\left\{[\mathrm{Cu}]_{\text {crust }} /[\mathrm{Ba}]_{\text {crust }}\right\}$ (Gabrielli and others, 2005), where $[\mathrm{Cu}]_{\text {crust }}$ and $[\mathrm{Ba}]_{\text {crust }}$ are 
Table 1. Main statistics of the records of the shallow core drilled on Alto dell'Ortles at $3830 \mathrm{~m}$ a.s.l. and comparison with other existing drilling sites in the Western Alps, on Col du Dôme (Preunkert and others, 2000) and Fiescherhorn (Schwikowski and others, 1999)

\begin{tabular}{|c|c|c|c|c|c|c|c|c|c|c|c|c|}
\hline & \multicolumn{6}{|c|}{ Alto dell'Ortles (3830 m) } & \multicolumn{3}{|c|}{ Col du Dôme (4250 m) } & \multicolumn{3}{|c|}{ Fiescherhorn (3890 m) } \\
\hline & Mean & SD & Median & Max & Min & Max/Min & Summer & Winter & Mean & Summer & Winter & Mean \\
\hline \multicolumn{13}{|l|}{ Stable isotopes $(\%$ ) } \\
\hline$\delta^{18} \mathrm{O}$ & -13 & 3 & -13 & -6 & -22 & 0.28 & - & - & - & -13 & -21 & -17 \\
\hline$\delta \mathrm{D}$ & -96 & 28 & -92 & -38 & -169 & 0.22 & $\sim-60$ & $\sim-140$ & $\sim-100$ & - & - & - \\
\hline \multicolumn{13}{|l|}{ Major ions $\left(\mathrm{ng} \mathrm{g}^{-1}\right)$} \\
\hline $\mathrm{F}^{-}$ & 1.8 & 2.0 & 1.3 & 15 & $>0.5$ & - & - & - & - & & & \\
\hline $\mathrm{Cl}^{-}$ & 85 & 60 & 69 & 341 & 12 & 28 & 43 & 17 & 30 & 58 & 50 & 53 \\
\hline $\mathrm{SO}_{4}^{2-}$ & 200 & 201 & 141 & 1210 & 24 & 51 & 620 & 180 & 400 & 438 & 253 & 324 \\
\hline $\mathrm{NO}_{3}{ }^{-}$ & 330 & 239 & 254 & 1232 & 50 & 25 & 440 & 120 & 280 & 210 & 135 & 167 \\
\hline $\mathrm{Na}^{+}$ & 43 & 37 & 33 & 207 & 3 & 68 & 25 & 11 & 18 & 31 & 30 & 29 \\
\hline $\mathrm{NH}_{4}^{+}$ & 139 & 125 & 108 & 764 & 4 & 170 & 180 & 13 & 97 & 128 & 29 & 80 \\
\hline $\mathrm{K}^{+}$ & 15 & 13 & 12 & 76 & 1 & 92 & - & - & - & 24 & 18 & 21 \\
\hline $\mathrm{Mg}^{2+}$ & 101 & 90 & 67 & 489 & 22 & 22 & - & - & - & 11 & 7 & 9 \\
\hline $\mathrm{Ca}^{2+}$ & 309 & 296 & 210 & 1882 & 55 & 34 & 62 & 29 & 46 & 108 & 99 & 96 \\
\hline $\begin{array}{l}\text { Dust } \\
\left(0.63-20 \mu \mathrm{m} \mathrm{mL}^{-1}\right)\end{array}$ & 150356 & 135832 & 116474 & 797932 & 25100 & 32 & - & - & - & - & - & - \\
\hline
\end{tabular}

provided by Wedepohl (1995). High concentrations of $\mathrm{Cu}$ and $\mathrm{Cd}$ at the bottom of the snow pit may thus distinguish the summer 2007 firn layers, in agreement with the snow sounding profile described.

While comparing the chemical and the glaciological observations, we note that the few ice lenses observed in the snow pit occur within the proposed summer layers, while the major discontinuities of the hardness index and the crystal size occur around the seasonal transitions (Fig. 7g). This supports the stratigraphic interpretation, based on chemical data, of the upper layers of the shallow core. Figure $7 f$ illustrates that the major $\mathrm{Ca}^{2+}$ and $\mathrm{Al}$ peaks correspond to the visually observed dust layers. Al, in particular, might be a more precise proxy of the dust layers than the more soluble $\mathrm{Ca}^{2+}$, due to the partial removal of the latter by meltwater percolation.

\section{DISCUSSION}

Although $T_{10}$ is close to PMT, the possibility remains that this glacier is still in a polythermal state. This would not be unusual in the Alps, as a glacier with similar exposure and elevation, Fiescherhorn glacier (3890 ma.s.I.) to the northwest, shows polythermal characteristics (Jenk and others, 2003). Indeed a model by Suter and others (2001) includes the Ortles-Cevedale massif among the high-altitude Alpine areas having the potential to contain cold ice. If polythermal conditions exist, this would be important for preserving long ice-core records.

From the $T_{\mathrm{s}}$ reconstruction we infer an average value of $-1.3^{\circ} \mathrm{C}$ at $3850 \mathrm{ma}$ a.s.l. in the Ortles mountain area during the most recent summers (2004-08). However, we note that the exceptionally warm summer of 2003 (Black and others, 2004), when $T_{\mathrm{s}}=2^{\circ} \mathrm{C}$ and the transient snowline increased to $\sim 3700 \mathrm{~m}$ in this area (Carturan, 2010), might have been a turning point for Alto dell'Ortles. According to our model, up to $\sim 600 \mathrm{~mm}$ w.e. of meltwater might have percolated through the firn that summer. This could have significantly affected the thermal state of this glacier as well as the environmental history recorded in the firn layers accumulated before 2003. We argue that the elevation (3820-3860 ma.s.I.) of the upper part of Alto dell'Ortles, as well as the rapid ongoing atmospheric warming, places this site at the lower limit at which the most recent firn layers have the potential to temporarily retain a seasonal record.

Despite the recent warmer conditions, both the data collected and our model provide evidence that the top part of Alto dell'Ortles is still accumulating mass at a rate of $\sim 800 \mathrm{~mm}$ w.e. $\mathrm{a}^{-1}$. According to our calculations, this may result from a total accumulation of $\sim 1200 \mathrm{mmw}^{-e} . \mathrm{a}^{-1}$ minus a summer melting of $\sim 400 \mathrm{~mm}$ w.e. $\mathrm{a}^{-1}$. Taking into account the vertical precipitation gradients, a total accumulation of $\sim 1200 \mathrm{~mm}$ w.e. is consistent with the annual precipitation rate expected in the 'inner dry Alpine zone' (Schwarb, 2000). We note that, while observations and calculations indicate that today at least part of the summer snow is melted, it appears that winter snow is not ablated by summer melting.

The lamination of the ice layers down to bedrock (Fig. 2c) is visually consistent with the shallow-core and snow-pit observations, along with the snow-sounding and GPR measurements that suggest this glacier is constructed of parallel and homogeneously distributed layers (Fig. 6a and b). Similarly to what was reported for suitable drilling sites in the Western Alps (Schwikowski and others, 1999; Preunkert and others, 2000), the concentration of insoluble dust, $\mathrm{Al}$ and ions of crustal origin $\left(\mathrm{Ca}^{2+}, \mathrm{Mg}^{2+}\right.$ and $\left.\mathrm{F}^{-}\right)$on Alto dell'Ortles cannot be linked clearly to seasonal deposition. Large fluctuations in the fallout rate of the crustal component are the product of the episodic nature of the deposition of Saharan dust (e.g. De Angelis and Gaudichet, 1991). In particular, the dust layer observed at $\sim 0.70 \mathrm{~m}$ depth (Fig. 7c-f) can be linked to a long-range transport event, which is substantiated by the small size $(<1.25 \mu \mathrm{m}$ diameter) of the dust in this peak.

Also, the fallout of the marine component of the aerosol (especially $\mathrm{Cl}^{-}$and $\mathrm{Na}^{+}$) does not show any marked seasonal behavior. While the $\mathrm{Cl}^{-} / \mathrm{Na}^{+}$median mass ratio of 2.1 supports a prevalent marine input (ratio 1.8) for these ions, it also indicates that preferential elution of $\mathrm{Cl}^{-}$due to 
meltwater percolation is insignificant (except in the short depth interval $8.88-9.13 \mathrm{~m}$ where the $\mathrm{Cl}^{-} / \mathrm{Na}^{+}$mass ratio is often $\sim 1$ ). A preferential elution of $\mathrm{Cl}^{-}$was in fact observed in the Perito Moreno (Southern Patagonia) core, diminishing the original $\mathrm{Cl}^{-} / \mathrm{Na}^{+}$ratio by $\sim 35 \%$ (Aristarain and Delmas, 1993). This suggests that meltwater percolation did not significantly affect the $\mathrm{Cl}^{-}$and $\mathrm{Na}^{+}$signal recorded in the recent snow and firn layers of Alto dell'Ortles.

Interestingly, while several chemical parameters seem to be affected by meltwater percolation in the deeper core layers (Fig. 7), the seasonality of $\delta \mathrm{D}, \delta^{18} \mathrm{O}, \mathrm{SO}_{4}{ }^{2-}, \mathrm{NO}_{3}{ }^{-}$, $\mathrm{NH}_{4}{ }^{+}, \mathrm{Cu}$ and $\mathrm{Cd}$ is fully retained within the uppermost 2008 and 2009 snow/firn layers, despite the effect of the warm year $2008\left(T_{\mathrm{s}}=-1.2^{\circ} \mathrm{C}\right)$ in the form of modeled meltwater percolation $(\sim 300 \mathrm{~mm})$. This provides confidence that before $\sim 1980$ (mean $T_{\mathrm{s}}=-3.7^{\circ} \mathrm{C}$ ), the atmospheric signal was permanently retained in the firn and thus in the underlying ice. In this case, the use of absolute time markers such as the 1977 Saharan dust horizon and the $1963{ }^{3} \mathrm{H}$ peak (Eichler and others, 2000) would be indispensable for dating the deep ice layers of an ice core extracted from this glacier.

Even assuming that heatwaves such as that of the summer of 2003 (Black and others, 2004) might have caused a massive meltwater percolation $(\sim 600 \mathrm{~mm})$ through the whole firn layer, an environmental history might still be preserved in the underlying ice. This was observed in the ice-core record from the Quelccaya ice cap, where borehole temperatures confirm that in 2003 this glacier was nearly isothermal (Thompson and others, 2006). Comparing the records from ice cores recovered in 2003 and in 1983, it is evident that in the $35 \mathrm{~m}$ section of the record deposited within that 20 year period, the $\delta^{18} \mathrm{O}$ record is smoothed substantially (Thompson and others, 2006). However, below the firn/ice transition the record so far is preserved through most of the core (Thompson and others, 1986, 2006). This can be explained by considering that percolating water was laterally drained at the firn/ice transition. The gentle slope characterizing the top part of Alto dell'Ortles may also have helped to drain any eventual excess of recent meltwater, thus protecting it from overprinting the record conserved in the underlying ice.

\section{CONCLUSIONS}

We report evidence that Alto dell'Ortles is remarkably thick $(\sim 70 \mathrm{~m})$, with an excellent lamination of the exposed ice layers down to bedrock. Although this glacier is still accumulating mass at the summit $\left(\sim 800 \mathrm{~mm} \mathrm{a}^{-1}\right)$, meltwater percolation through the firn was significant during the exceptionally warm summers of the last decade. Despite this, the seasonal chemical signal is clearly preserved within the uppermost 2008 and 2009 snow/firn layers. Therefore this glacier is likely to have retained most of its environmental history in the ice formed before $\sim 1980$, when summer air temperature was $\sim 2^{\circ} \mathrm{C}$ lower than today in this area.

However, the unique environmental ice-core record retained in Alto dell'Ortles is at risk due to the expected increasing trend in summer temperatures (Déqué, 2009). At lower elevations, the glaciers surrounding Ortles mountain have already experienced strong ablation, resulting in largely negative mass balances during the last decade (e.g. Fontana Bianca and Vedretta Lunga glaciers; Ufficio Idrografico, 2009). Particularly striking is the case of Ghiacciaio del Caresér, located $\sim 15 \mathrm{~km}$ southeast of Ortles mountain, and extending from $\sim 2900$ to $\sim 3200$ ma.s.I. In 1980 its mass balance became negative, and from 1980 to 2001 it underwent an average loss of $>1 \mathrm{~m}_{\text {ice }} \mathrm{a}^{-1}$. Since 2003 the mass loss rate has nearly doubled (Carturan and Seppi, 2007).

There exists the alarming possibility that glacier retreat in this area is accelerating, as is happening around the world (Zemp and others, 2009). This phenomenon could, in particular, affect Alpine glaciers located in the area of the Mediterranean that is predicted to warm strongly during the next few decades (Déqué, 2009). Subsequently, many Alpine glaciers are expected to disintegrate rapidly and vanish within the same time period (Zemp and others, 2006). In this case, the upper part of Alto dell'Ortles will likely be affected by stronger melting. Consequently a unique environmental record is at risk of being lost.

\section{ACKNOWLEDGEMENTS}

This work is a contribution to the 'Ortles project', a program supported by the Fire Protection and Civil Division of the Autonomous Province of Bolzano (H. Staffler, M. Munari), in collaboration with the Forest Division of the Autonomous Province of Bolzano (P. Profanter, B. Folie, R. Pinggera) and the Stelvio National Park (W. Platter). This is Ortles project publication No. 1. For collaboration in the various phases of the field operations we thank L. Noessig, V. Mair, E. Wolfsgruber and C. Carraro (Ufficio geologia e prove materiali of the Autonomous Province of Bolzano), M. Zebisch and P. Rastner (European Academy Bozen/ Bolzano), P. Vallelonga (University of Venice), M. Lanzinger, M. Cattadori and R. Filippi (Museo Tridentino di Scienze Naturali) and S. Forti (Istituto di Cultura le Marcelline). For logistic support we thank T. Stocker (Alpine guides of Solda), the Airway helicopter company, M. Andrighettoni, F. Raffaelli and A. Stinghen (SAT Rovereto). We are also grateful to Ping-Nan Lin (OSU) for stable-isotope analysis. Finally we acknowledge M. Frezzotti (Italian National Agency for New Technologies, Energy and the Environment), M. Schwikowski (Paul Scherrer Institute) and two anonymous reviewers for providing useful comments that helped to improve the manuscript. This is Byrd Polar Research Center contribution No. 1401.

\section{REFERENCES}

Aristarain, A.J. and R.J. Delmas. 1993. Firn-core study from the southern Patagonia ice cap, South America. J. Glaciol., 39(132), 249-254.

Barbante, C. and 6 others. 1999. Trace element determination in alpine snow and ice by double focusing inductively coupled plasma mass spectrometry with microconcentric nebulization. J. Analy. Atom. Spectrom., 14(9), 1433-1438.

Barbante, C. and 14 others. 2004. Historical record of European emissions of heavy metals to the atmosphere since the $1650 \mathrm{~s}$ from alpine snow/ice cores drilled near Monte Rosa. Environ. Sci. Technol., 38(15), 4085-4090.

Baroni, C. and G. Orombelli. 1996. The Alpine 'iceman' and Holocene climatic change. Quat. Res., 46(1), 78-83.

Black, E., M. Blackburn, G. Harrison, B. Hoskins and J. Methven. 2004. Factors contributing to the summer 2003 European heatwave. Weather, 59(8), 217-223.

Bortenschlager, S., W. Kofler, K. Oeggl and W. Schoch. 1992. Erste Ergebnisse der Auswertung der vegetabilischen Reste vom Hauslabjochfund. In Höpfel, F., W. Platzer and K. Spindler, eds. Der Mann im Eis: Band 1. Innsbruck, Universität Innsbruck, 307-312. 
Buck, C.F., P.A. Mayewski, M.J. Spencer, S. Whitlow, M.S. Twickler and D. Barrett. 1992. Determination of major ions in snow and ice cores by ion chromatography. J. Chromatogr., 594(1-2), 225-228.

Carturan, L. 2010. Effetto delle variazioni climatiche sulla criosfera e sull'idrologia dei bacini d'alta quota. (PhD thesis, Università degli Studi di Padova.)

Carturan, L. and R. Seppi. 2007. Recent mass balance results and morphological evolution of Careser Glacier (Central Alps). Geogr. Fís. Din. Quat., 30(1), 33-42.

Craig, H. 1957. Isotopic standards for carbon and oxygen and correction factors for mass-spectrometric analysis of carbon dioxide. Geochim. Cosmochim. Acta, 12(1-2), 133-149.

Craig, H. 1961. Isotopic variations in meteoric waters. Science, 133(3465), 1702-1703.

Davis, B.A.S., S. Brewer, A.C. Stevenson, J. Guiot and Data Contributors. 2003. The temperature of Europe during the Holocene reconstructed from pollen data. Quat. Sci. Rev., 22(15-17), 1701-1716.

De Angelis, M. and A. Gaudichet. 1991. Saharan dust deposition over Mont Blanc (French Alps) during the last 30 years. Tellus, 43B(1), 61-75.

Déqué, M. 2009. Temperature and precipitation probability density functions in ENSEMBLES regional scenarios. Exeter, Meteorological Office. Hadley Centre. (ENSEMBLES Tech. Rep. 5.)

Eichler, A. and 7 others. 2000. Glaciochemical dating of an ice core from upper Grenzgletscher (4200 m a.s.I.). J. Glaciol., 46(154), 507-515.

Eichler, A., M. Schwikowski, M. Furger, U. Schotterer and H.W. Gäggeler. 2004. Sources and distribution of trace species in Alpine precipitation inferred from two 60-year ice core paleorecords. Atmos. Chem. Phys. Discuss., 4, 71-108.

Eisen, O., U. Nixdorf, L. Keck and D. Wagenbach. 2003. Alpine ice cores and ground penetrating radar: combined investigations for glaciological and climatic interpretations of a cold Alpine ice body. Tellus, 55B(5), 1007-1017.

Fierz, C. and 8 others. 2009. The international classification for seasonal snow on the ground. Paris, UNESCO-International Hydrologic Programme. (IHP Technical Documents in Hydrology 83.)

Frei, C. and C. Schär. 1998. A precipitation climatology of the Alps from high-resolution rain-gauge observations. Int. J. Climatol., 18(8), 873-900.

Frisia, S., A. Borsato, N. Preto and F. McDermott. 2003. Late Holocene annual growth in three Alpine stalagmites records the influence of solar activity and the North Atlantic Oscillation on winter climate. Earth Planet. Sci. Lett., 216(3), 411-424.

Frisia, S., A. Borsato, I.M. Spötl, I.M. Villa and F. Cucchi. 2005. Climate variability in the SE Alps of Italy over the past 17000 years reconstructed from a stalagmite record. Boreas, 34(4), 445-455.

Frolov, A.D. and Yu.Ya. Macheret. 1999. On dielectric properties of dry and wet snow. Hydrol. Process., 13(12-13), 1755-1760.

Gabrieli, J. and 11 others. 2010. Post 17th-century changes of European $\mathrm{PAH}$ emissions recorded in high-altitude Alpine snow and ice. Environ. Sci. Technol., 44(9), 3260-3266.

Gabrielli, P. and 9 others. 2005. Variations in atmospheric trace elements in Dome C (East Antarctica) ice over the last two climatic cycles. Atmos. Environ., 39(34), 6420-6429.

Gabrielli, P., G. Cozzi, S. Torcini, P. Cescon and C. Barbante. 2008. Trace elements in winter snow of the Dolomites (Italy): a statistical study of natural and anthropogenic contributions. Chemosphere, 72(10), 1504-1509.

Haeberli, W., R. Frauenfelder, A. Kääb and S. Wagner. 2004. Characteristics and potential climatic significance of 'miniature ice caps' (crest- and cornice-type low-altitude ice archives). J. Glaciol., 50(168), 129-136.

Hock, R. 2003. Temperature index melt modelling in mountain areas. J. Hydrol., 282(1-4), 104-115.

Hubbard, B. and N. Glasser. 2005. Field techniques in glaciology and glacial geomorphology. New York, John Wiley \& Sons.
Jenk, T.M. 2006. Rekonstruktion von Klima und anthropogenen Einflüssen im Alpenraum anhand eines Eisbohkerns vom Fiescherhorngletscher. (PhD thesis, Universität Bern and Paul Scherrer Institut.)

Jenk, T., H.W. Gäggeler, A.A. Schwerzmann and M. Schwikowski. 2003. Recovery of a $150 \mathrm{~m}$ ice core down to bedrock from the Fiescherhorn Glacier. Villingen, Paul Scherrer Institut. (Annual Report 2002.)

Jenk, T.M. and 9 others. 2009. A novel radiocarbon dating technique applied to an ice core from the Alps indicating late Pleistocene ages. J. Geophys. Res., 114(D14), D14305. (10.1029/2009JD011860.)

Kappenberger, G. and J. Kerkmann. 1997. Il tempo in montagna: manuale di meteorologia alpina. Milano, Zanichelli.

Keck, L. 2001. Climate significance of stable isotope records from Alpine ice cores. (PhD thesis, Ruprecht-Karls-Universität Heidelberg.)

Kutschera, W. and W. Müller. 2003. 'Isotope language' of the Alpine Iceman investigated with AMS and MS. Nucl. Instrum. Meth. Phys. Res. B, 204, 705-719.

Luterbacher, J., D. Dietrich, E. Xoplaki, M. Grosjean and H. Wanner. 2004. European seasonal and annual temperature variability, trends, and extremes since 1500. Science, 303(5663), 1499-1503.

Moran, T. and S. Marshall. 2009. The effects of meltwater percolation on the seasonal istopic signals in an Arctic snowpack. J. Glaciol., 55(194), 1012-1024.

Nyeki, S. and 11 others. 2000. Convective boundary layer evolution to $4 \mathrm{~km}$ asl over high-Alpine terrain: airborne lidar observations in the Alps. Geophys. Res. Lett., 27(5), 689-692.

Ohmura, A. 2001. Physical basis for the temperature-based meltindex method. J. Appl. Meteorol., 40(4), 753-761.

Paterson, W.S.B. 1994. The physics of glaciers. Third edition. Oxford, etc., Elsevier.

Preunkert, S., D. Wagenbach, M. Legrand and C. Vincent. 2000. Col du Dôme (Mt Blanc Massif, French Alps) suitability for ice core studies in relation with past atmospheric chemistry over Europe. Tellus, 52B(3), 993-1012.

Reijmer, C.H. and R. Hock. 2008. Internal accumulation on Storglaciären, Sweden, in a multi-layer snow model coupled to a distributed energy- and mass-balance model. J. Glaciol., 54(184), 61-72.

Schneider, T. and P. Jansson. 2004. Internal accumulation in firn and its significance for the mass balance of Storglaciären, Sweden. J. Glaciol., 50(168), 25-34.

Schwarb, M. 2000. The Alpine precipitation climate: evaluation of a high-resolution analysis scheme using comprehensive raingauge data. (MSc thesis, ETH Zürich.)

Schwikowski, M., S. Brütsch, H.W. Gäggeler and U. Schotterer. 1999. A high-resolution air chemistry record from an Alpine ice core: Fiescherhorn glacier, Swiss Alps. J. Geophys. Res., 104(D11) 13,709-13,719.

Schwikowski, M. and 11 others. 2004. Post-17th-century changes of European lead emissions recorded in high-altitude alpine snow and ice. Environ. Sci. Technol., 38(4), 957-964.

Seidler, H. and 7 others. 1992. Some anthropological aspects of the prehistoric Tyrolean ice man. Science, 258(5081), 455-457.

Sigl, M. and 9 others. 2009. Towards radiocarbon dating of ice cores. J. Glaciol., 55(194), 985-996.

Span, N., A. Fischer, M. Kuhn, M. Massimo and M. Butschek. 2005. Radarmessungen der Eisdicke Österreichischer Gletscher. Band I: Messungen 1995 bis 1998. Österreich. Beitr. Meteorol. Geophys. 33.

Suter, S., M. Laternser, W. Haeberli, R. Frauenfelder and M. Hoelzle. 2001. Cold firn and ice of high-altitude glaciers in the Alps: measurements and distribution modelling. J. Glaciol., 47(156), 85-96.

Thevenon, F., F.S. Anselmetti, S.M. Bernasconi and M. Schwikowski. 2009. Mineral dust and elemental black carbon records 
from an Alpine ice core (Colle Gnifetti glacier) over the last millennium. J. Geophys. Res., 114(D17), D17102. (10.1029/ 2008JD011490.)

Thompson, L.G. 1977. Microparticles, ice sheets and climate. Inst. Polar Stud. Rep. 64.

Thompson, L.G. 1980. Glaciological investigations of the tropical Quelccaya ice cap, Peru. J. Glaciol., 25(91), 69-84.

Thompson, L.G., E. Mosley-Thompson, W. Dansgaard and P.M. Grootes. 1986. The Little Ice Age as recorded in the stratigraphy of the tropical Quelccaya ice cap. Science, 234(4774), 361-364.

Thompson, L.G. and 8 others. 2006. Abrupt tropical climate change: past and present. Proc. Natl. Acad. Sci. USA (PNAS), 103(28), 10,536-10,543.

Trabant, D.C. and L.R. Mayo. 1985. Estimation and effects of internal accumulation on five glaciers in Alaska. Ann. Glaciol., 6, 113-117.

Ufficio Idrografico, Provincia di Bolzano. 2009. Glacierreport: Ghiacciaio di Fontana Bianca N. 01 and Vedretta Lunga N. 02 (Anno idrologico 2007/2008). Bolzano, Ufficio Idrografico di Bolzano.
Van de Velde, K. and 8 others. 2000. A two hundred years record of atmospheric cadmium, copper and zinc concentrations in high altitude snow and ice from the French-Italian Alps. Geophys. Res. Lett., 27(2), 249-252.

Villa, S., M. Vighi, V. Maggi, A. Finizio and E. Bolzacchini. 2003. Historical trends of organochlorine pesticides in an Alpine glacier. J. Atmos. Chem., 46(3), 295-311.

Wagenbach, D., K.O. Münnich, U. Schotterer and H. Oeschger. 1988. The anthropogenic impact on snow chemistry at Colle Gnifetti, Swiss Alps. Ann. Glaciol., 10, 183-187.

Wedepohl, K.H. 1995. The composition of the continental crust. Geochim. Cosmochim. Acta, 59(7), 1217-1232.

Zagorodnov, V., O. Nagornov and L.G. Thompson. 2006. Influence of air temperature on a glacier's active-layer temperature. Ann. Glaciol., 43, 285-291.

Zemp, M., W. Haeberli, M. Hoelzle and F. Paul. 2006. Alpine glaciers to disappear within decades? Geophys. Res. Lett., 33(13), L13504. (10.1029/2006GL026319.)

Zemp, M., M. Hoelzle and W. Haeberli. 2009. Six decades of glacier mass-balance observations: a review of the worldwide monitoring network. Ann. Glaciol., 50(50), 101-111.

MS received 3 May 2010 and accepted in revised form 26 August 2010 